\title{
PERBEDAAN PENGARUH PEMBERIAN MINYAK KELAPA SAWIT (Palm Oi) DAN MINYAK KELAPA MURNI (Virgin Coconut Oi) TERHADAP PERBAIKAN PROFIL LEMAK (KOLESTEROL) PADA TIKUS DENGAN DIET ATEROGENIK
}

\section{THE DIFFERENT EFFECTS OF GIVING PALM OIL AND VIRGIN COCONUT OIL ON IMPROVED LIPID PROFILE (CHOLESTEROL) OF RATS WITH ATHEROGENIC DIET}

\author{
Inggita Kusumastuty ${ }^{*}$, Sri Andarini**, Anak Agung Gede Anom Aswin ${ }^{* * *}$ \\ * Program Studi Ilmu Gizi Kesehatan Fakultas Kedokteran Universitas Brawijaya Malang \\ ** Laboratorium IImu Kesehatan Masyarakat - Kedokteran Pencegahan Fakultas Kedokteran Universitas Brawijaya Malang \\ ${ }^{* * *}$ Politeknik Kesehatan Jurusan Gizi Malang
}

\begin{abstract}
Virgin Coconut Oil (VCO) is a kind of coconut oil that most of its contained is Medium Chain Fatty Acids (MCFA) and previous stdy showed that MCFA has an ability to prevent vascular desease. This experiment was done to prove the ability of virgin coconut oil to reduce cholesterol total of rats with atherogenic diet compared with palm oil. This experiment was designed as true pre test post test experiment with control groups. The number of samples were 24 male wistar rats and they were separated into 4 treatment groups in which each of them has 2 diet sections. The First section was done within 8 weeks, group A got normal diet, group B, C and D got atherogenic diet with lard, after this section finished all of the groups got cholesterol pre test level. The next 4 weeks, in the second section treatment diet, group A got normal diet, group $B$ got atherogenic diet with lard, group $C$ got atherogenic diet with palm oil and group $D$ got atherogenic diet with virgin coconut oil, after the second section was over rat cholesterol levels were measured by enzymatic photometric test base on "CHO-PAP". The results from One Way Anova which was continued to Tukey test showed that group $B, C$ and $D$ were homogenous, but they were different significantly againts group $A$ on pre test with $p(0.001)<0.05$. Post test result showed that group $A$ wasn't different from group $D$, and both of them different significantly from group $B$ and $C$ at $p(0.000)$ $<0.05$. Paired T-test showed that the decrease level of cholesterol between post test with pre test of group $D(45 \mathrm{mg} / \mathrm{dl})$ is higher than group $C(35.5 \mathrm{mg} / \mathrm{dl})$. It can be concluded that virgin coconut oil is better than palm oil in decreasing cholesterol level.
\end{abstract}

Key words: Palm Oil, Virgin Coconut Oil, Medium Chain Fatty Acids, Atherogenic Diet, Cholesterol

\section{PENDAHULUAN}

Di Indonesia, kelapa memang sulit dipisahkan dalam kehidupan sehari-hari, baik oleh masyarakat pedesaan maupun perkotaan. Cara penyajiannyapun beragam. Ada yang disajikan sebagai hidangan utama, campuran sayur, bumbu maupun minuman. Banyak orang mengatakan bahwa minyak kelapa mengandung lemak jenuh dan hal ini dikaitkan dengan pembentukan plak didinding pembuluh darah. Plak ini akhirnya menyumbat pembuluh darah dan menyebabkan berbagai penyakit, seperti jantung, stroke dan gangguan ginjal (1).

Anggapan dari sebagian masyarakat ini mengakibatkan minyak kelapa dihindari dari diet hariannya baik secara langsung maupun tidak langsung. Kurangnya informasi ilmiah tentang manfaat minyak kelapa bagi kesehatan menjadikan minyak kelapa ini mendapatkan opini

Jurnal Kedokteran Brawijaya, Vol. XXII, No. 3, Desember 2006 Korespondensi: Inggita Kusumastuty; Program Studi Gizi Kesehatan Fakultas Kedokteran Unibraw Malang; Jl. Veteran Malang 65145; 0341 - 580993 ext. 127 yang negatif dibandingkan dengan minyak kelapa sawit, minyak kedelai dan minyak jagung. Bahkan, kini minyak kelapa relatif sulit ditemukan dipasar-pasar tradisional karena sudah didominasi dengan minyak goreng yang berasal dari minyak kelapa sawit. Padahal, Indonesia adalah produsen kelapa utama di dunia (2).

Produksi minyak kelapa sawit dari tahun ke tahun terus meningkat yaitu mencapai 3.675,4 juta liter pada tahun 1996 (BPS, 1997). Kandungan asam lemak yang terbanyak dari minyak ini adalah asam lemak tak jenuh. Inilah sebab mengapa masyarakat lebih menyukai produk ini. Asam lemak jenuh yang lebih sedikit ini mengakibatkan rendahnya kandungan Medium Chain Fatty acid (MCFA) dari minyak kelapa sawit (3).

Virgin coconut oil (VCNO) merupakan salah satu bentuk olahan minyak kelapa yang sedang berkembang saat ini. VCNO dibuat dari pemanfaatan buah kelapa segar. Minyak ini diklasifikasikan sebagai vegetable oil. Kandungan lemak jenuh terbesar dari minyak kelapa ini adalah MCFA. Medium Chain Fatty Acids ini mempunyai sifat- sifat metabolisme yang sangat berbeda dengan long chain fatty 
acid yaitu lebih mudah diserap, dicerna dan diangkut sehingga sering disebut sebagai sumber energi siap pakai. Hal ini merupakan alasan utama minyak ini diduga memiliki kegunaan bagi kesehatan seseorang. Pengolahan VCNO yang tidak menggunakan panas tinggi ini menyebabkan vitamin $\mathrm{E}$ tetap dapat dipertahankan (4).

Virgin Coconut Oil adalah lemak jenuh tersehat yang ada, tetapi sayangnya saat ini paradigma yang mewaspadai penggunaan lemak jenuh terhadap kejadian penyakit vaskuler tertanam kuat dalam masyarakat. Penyakit vaskuler merupakan suatu penyakit yang ditakuti oleh masyarakat. Penyakit ini merupakan penyakit yang berbahaya dan mematikan. Salah satu indikasi munculnya penyakit vaskuler ini adalah tingginya kolesterol dalam darah. Selain itu, kejadian aterosklerosis juga bertalian erat dengan penyimpangan metabolisme kolesterol dalam tubuh, karena tingginya kolesterol dalam darah menyebabkan pengendapan kolesterol pada dinding pembuluh darah.

Beberapa penelitian mengindikasikan lemak jenuh terutama yang diperoleh melalui penggunaan VCNO bermanfaat dalam mencegah terjadinya gangguan jantung dan sirkulasi, menurunkan berat badan, mencegah kejadian kanker serta memiliki kemampuan antimikroba (5).

Melihat manfaat kesehatan yang dimiliki oleh VCNO dan bahan bakunya yang berlimpah di Indonesia sehingga perlu untuk mengetahui seberapa besar pengaruhnya untuk memperbaiki kesehatan seseorang. Penelitian ini bertujuan membandingkan efek VCNO dengan minyak kelapa sawit khususnya terhadap penurunan kadar kolesterol total pada tikus yang diberi diet aterogenik.

\section{METODE}

\section{Desain Penelitian}

Penelitian ini merupakan eksperimen laboratorium dengan menggunakan jenis Rancangan Pretest Postest dengan kelompok kontrol (6). Kelompok dibagi menjadi 4 yaitu kelompok $A, B, C$ dan $D$ dengan sistem pengacakan menggunakan Rancangan Acak Lengkap.

\section{Sampel}

Sampel ditetapkan berdasarkan kriteria inklusi dan eksklusi. Kriteria inklusi antara lain tikus jenis Rattus Novergicus Galur Wistar, jenis kelamin jantan, umur 6-8 minggu, berat 120-160 gram, warna bulu putih, dan tikus aktif. Sedangkan kriteria eksklusi antara lain tikus tidak mau makan dan tikus yang mengalami penurunan keadaan fisik atau mati

Pemilihan hewan coba tikus dikarenakan tikus adalah hewan coba yang sering digunakan karena keterdekatannya dengan manusia. Keterdekatan tersebut antara lain adalah mamalia, pemakan sembarang (omnivora), mudah berkembang biak dan mudah mendapat perlakuan. Selain itu ada dua sifat yang membedakan tikus dengan hewan coba lainnya yaitu tikus tidak dapat muntah karena struktur anatomis yang tidak lazim yaitu ditempat esofagus bermuara kedalam lambung. Kedua, tikus tidak mempunyai kandung empedu (7). Dari sifat tersebut diharapkan perlakuan yang diberikan pada tikus berupa pemberian makan dapat diterima dengan baik oleh tikus tanpa dimuntahkan kembali.

Untuk 4 macam perlakuan diperlukan jumlah sampel atau ulangan paling sedikit 5 kali untuk masing-masing perlakuan. Akan tetapi diperlukan penambahan pengulangan pada setiap perlakuan sebagai cadangan dan ditetapkan sejumlah 1 kali pengulangan. Sehingga total sampel yang dibutuhkan sejumlah 24 ekor tikus dengan rincian 6 ekor tikus untuk masing-masing perlakuan. Pada penelitian ini terdapat 4 macam perlakuan yaitu kelompok $A$ (tikus dengan pemberian diet normal), kelompok $B$ (tikus dengan pemberian diet aterogenik dengan minyak babi), kelompok C (tikus dengan pemberian diet aterogenik dengan minyak kelapa sawit) dan kelompok $D$ (tikus dengan pemberian diet aterogenik dengan VCNO)

Sistem pengacakan menggunakan Rancangan Acak Lengkap sebagai berikut : dari jumlah sampel 24 ekor tikus ini kemudian dilakukan pengacakan untuk memperoleh prinsip randomisasi dalam menentukan unit percobaan. Jumlah unit percobaan adalah 24 dengan 4 kelompok sehingga masing-masing kelompok terdiri dari 6 ekor tikus, setiap tikus diberi nomor dari 1-24.

\section{Metode Pengumpulan Data}

Data diperoleh dari analisa yang dilakukan pada seluruh kelompok hewan coba yaitu analisa berat badan yang dilakukan 1 minggu sekali dan analisa kolesterol total yang dilaksanakan pada awal dan akhir eksperimen.

\section{Prosedur Pemeriksaan Kolesterol}

Setelah pemberian diet selama 8 minggu dan 4 minggu kemudian tikus diperiksa kadar kolesterol darahnya. Terlebih dahulu dilakukan pengambilan darah untuk dijadikan serum. Metode yang digunakan dalam pemeriksaan kolesterol total adalah "CHO-PAP": enzymatic photometric test. Serum tikus yang telah didapat diambil $10 \mu \mathrm{l}$ dan dicampur dengan pereaksi kolesterol $1000 \mu \mathrm{l}$ dan diinkubasikan selama 5 menit pada suhu $37^{\circ} \mathrm{C}$. Selanjutnya dibaca pada spektofotometer pada panjang gelombang $546 \mathrm{~nm}$.

\section{Pengolahan dan Analisis Data}

Untuk mengetahui perbedaan rata-rata kadar kolesterol total dan berat badan digunakan uji statistik One Way Anova. Hasil pengujian yang diperoleh digunakan untuk menggambarkan apakah ada pengaruh pemberian diet normal (kelompok A), diet aterogenik minyak babi (kelompok B), diet aterogenik minyak kelapa sawit (kelompok C), diet aterogenik VCNO (kelompok D) secara bermakna atau tidak. Jika ada perbedaan dilanjutkan dengan Pos Hoc Tukey untuk mengetahui pasangan data yang berbeda. Untuk mengetahui perbedaan data pre test dan post test digu- 
nakan Paired T-Test. Pengujian statistik dilakukan dengan SPSS 10.00 pada tingkat kepercayaan $95 \%$.

\section{HASIL PENELITIAN \\ Asupan Energi dan Zat Gizi}

Pada Gambar 1. rata-rata asupan pakan dan energi pada kelompok A dan B (kontrol) diet pada pre maupun post test sama. Akan tetapi, pada kelompok $C$ dan $D$ diet berbeda. Pada tiap kelompok tersebut diberikan jumlah energi yang sama walaupun jenis diet berbeda yaitu sebesar 104.78 Kalori. Untuk mendapatkan nilai Kalori yang sama maka, pada diet normal diberikan jumlah pakan yang lebih banyak dibandingkan dengan diet aterogenik. Pada diet normal total pemberian pakan adalah sebesar 30.5 gram, sedangkan pada diet aterogenik dengan minyak babi, minyak kelapa sawit maupun VCNO diberikan sebesar 26 gram (8). Pada kelompok A, B dan D rata-rata asupan energi dan zat gizi pre dan post test memiliki gambaran meningkat akan tetapi pada kelompok $\mathrm{C}$ memiliki gambaran menurun dilihat dari perhitungan asupan makan pada pre dan post test. Penurunan asupan energi pada kelompok C ini sebesar 2.62 Kalori.

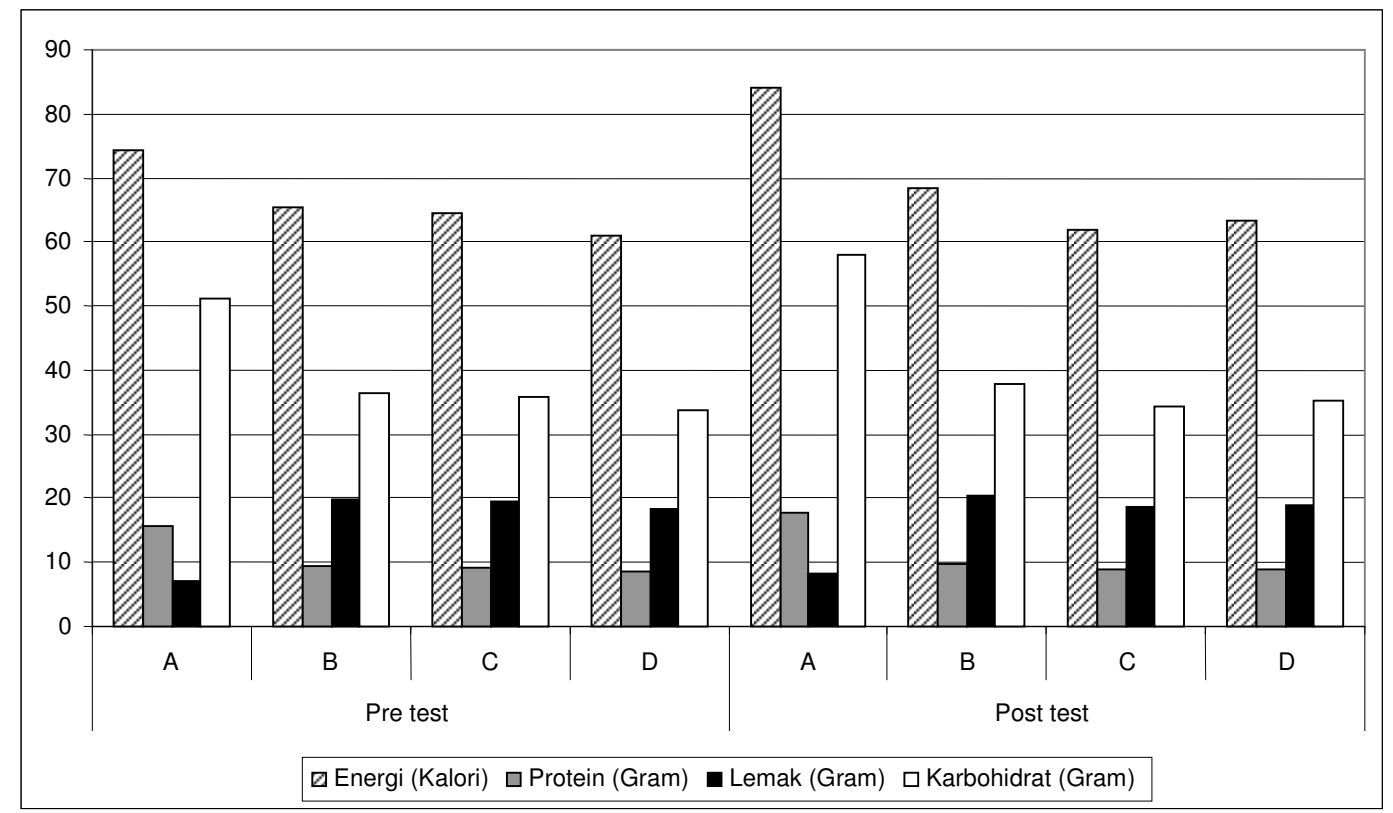

Gambar 1. Diagram Rata-rata Asupan Energi dan Zat Gizi

Keterangan:Rata-rata asupan energi dan zat gizi post test kelompok A (diet normal), B (diet aterogenik minyak babi), dan D (diet aterogenik VCNO) meningkat, sedangkan kelompok $\mathrm{C}$ (diet aterogenik minyak kelapa sawit) menurun.

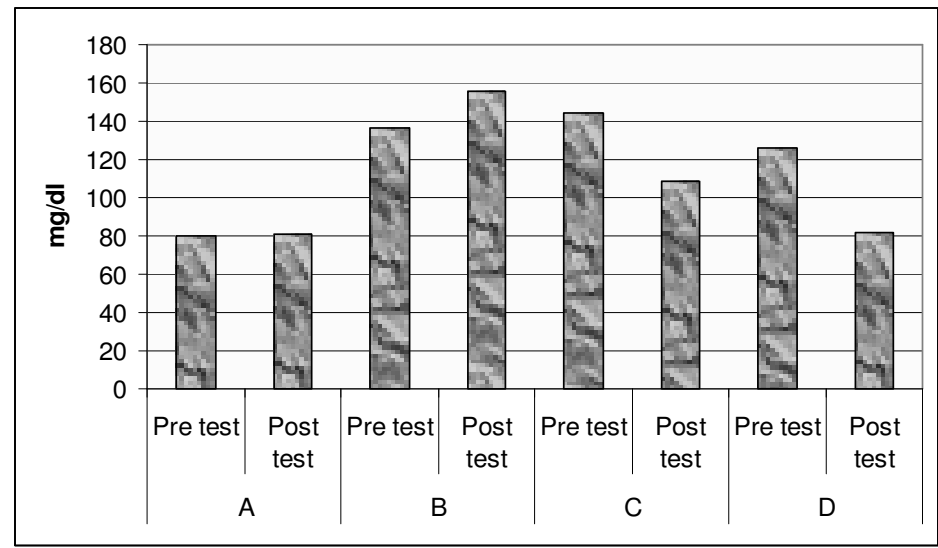

Gambar 2. Diagram Kadar Kolesterol

Keterangan: Uji statistik Tukey-test berpasangan menunjukkan bahwa tidak ada perbedaan perubahan antara kadar kolesterol total sebelum dan sesudah test pada kelompok $A$ dengan $p(0.644)>0.05$. Adanya perbedaan perubahan antara kadar kolesterol total sebelum dan sesudah test didapatkan pada kelompok $B$ dengan $p(0.004)<0.05$, kelompok $C$ dengan $p$ $(0.006)<0.05$ dan kelompok $D$ dengan $p(0.001)<0.05$. 
Dari eksperimen yang telah dilakukan diketahui bahwa rata-rata asupan pada semua kelompok berkisar antara 60.85 Kalori hingga 84.1 Kalori atau $58.12 \%$ hingga $80 \%$ kecukupan yang seharusnya. Rata-rata asupan energi pada saat pre test tertinggi pada kelompok $A$ yaitu sebesar 74.33 Kalori atau $70.9 \%$ dari total pakan yang diberikan. Sedangkan rata-rata asupan energi terendah didapatkan pada kelompok $D$ yaitu sebesar 60.85 Kalori atau $58.12 \%$ dari total pakan yang diberikan.

\section{Kadar Kolesterol}

Dari hasil pemeriksaan kadar kolesterol dapat diketahui bahwa kadar kolesterol pada saat pretest pada kelompok $\mathrm{A}$ jauh lebih rendah dibandingkan dengan kelompok $\mathrm{B}, \mathrm{C}$ dan $\mathrm{D}$. Pada kelompok A didapatkan ratarata kadar kolesterol pre test sebesar $79.67 \mathrm{mg} / \mathrm{dl}$, sedangkan pada kelompok B sebesar $136.83 \mathrm{mg} / \mathrm{dl}$, kelompok $C$ sebesar $144.17 \mathrm{mg} / \mathrm{dl}$ dan kelompok D sebesar $126.33 \mathrm{mg} / \mathrm{dl}$. Dari perbedaan data tersebut maka perlunya diketahui perbedaan secara statistik.

Dari hasil pengujian One-way Anova pre test menunjukkan bahwa diet normal (kelompok A), diet aterogenik dengan minyak babi (kelompok B), diet aterogenik dengan minyak kelapa sawit (kelompok C) dan diet aterogenik dengan VCNO (kelompok D) memberikan pengaruh yang berbeda terhadap kadar kolesterol total dengan $P(0.001)<0.05$. Dengan adanya perbedaan yang signifikan tersebut maka dilanjutkan dengan uji Tukey (Beda Nyata Terkecil) dan menunjukkan bahwa kelompok A berbeda dengan kelompok B, C dan D. Sedangkan, kelompok $\mathrm{B}, \mathrm{C}$ dan $\mathrm{D}$ tidak berbeda.

Hasil kadar kolesterol (Gambar 2) pada saat post test menunjukkan hasil yang berbeda-beda. Rata-rata kadar kolesterol kelompok A sebesar $80.67 \mathrm{mg} / \mathrm{dl}$, kelompok B sebesar $156 \mathrm{mg} / \mathrm{dl}$, kelompok C sebesar $108.67 \mathrm{mg} / \mathrm{dl}$ dan kelompok D sebesar $69.83 \mathrm{mg} / \mathrm{dl}$.

Dengan perbedaan hasil post test ini maka perlunya dibuktikan perbedaan secara uji statistik. Hasil pengujian One-way Anova post test menunjukkan bahwa diet normal (kelompok A), diet aterogenik dengan minyak babi (kelompok B), diet aterogenik dengan minyak kelapa sawit (kelompok C) dan diet aterogenik dengan VCNO (kelompok D) memberikan pengaruh yang berbeda terhadap kadar kolesterol total dengan $P(0.000)<0.05$. Pada uji lanjut dengan Tukey (Beda Nyata Terkecil) menunjukkan bahwa kelompok $\mathrm{A}$ berbeda dengan kelompok $\mathrm{B}$ dan $\mathrm{C}$. Akan tetapi kelompok $A$ tidak berbeda dengan kelompok $D$.

Dari data pre dan post test diketahui bahwa pada kelompok $A$ mengalami kenaikan dengan rata-rata kenaikan sebesar $1 \mathrm{mg} / \mathrm{dl}$, pada kelompok B mengalami kenaikan dengan rata-rata kenaikan sebesar $19.17 \mathrm{mg} / \mathrm{dl}$, pada kelompok $\mathrm{C}$ mengalami penurunan dengan rata-rata penurunan sebesar $35.50 \mathrm{mg} / \mathrm{dl}$ dan pada kelompok $D$ mengalami penurunan dengan rata-rata penurunan sebesar
$45 \mathrm{mg} / \mathrm{dl}$. Dengan adanya perbedaan ini maka kadar kolesterol pre dan post test ini maka perlunya dibuktikan secara uji statistik.

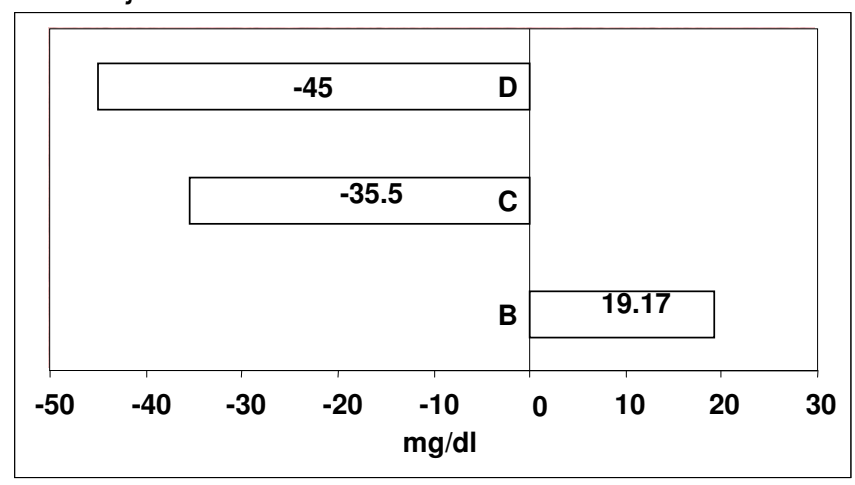

\section{Gambar 3. Diagram Perubahan Kadar Kolesterol Total}

Uji statistik Tukey-test berpasangan menunjukkan bahwa tidak ada perbedaan perubahan antara kadar kolesterol total sebelum dan sesudah test pada kelompok $A$ dengan $P(0.644)>0.05$. Adanya perbedaan perubahan antara kadar kolesterol total sebelum dan sesudah test didapatkan pada kelompok B dengan $P(0.004)<0.05$, kelompok $C$ dengan $P(0.006)<0.05$ dan kelompok $D$ dengan $P(0.001)<0.05$.

\section{Berat Badan}

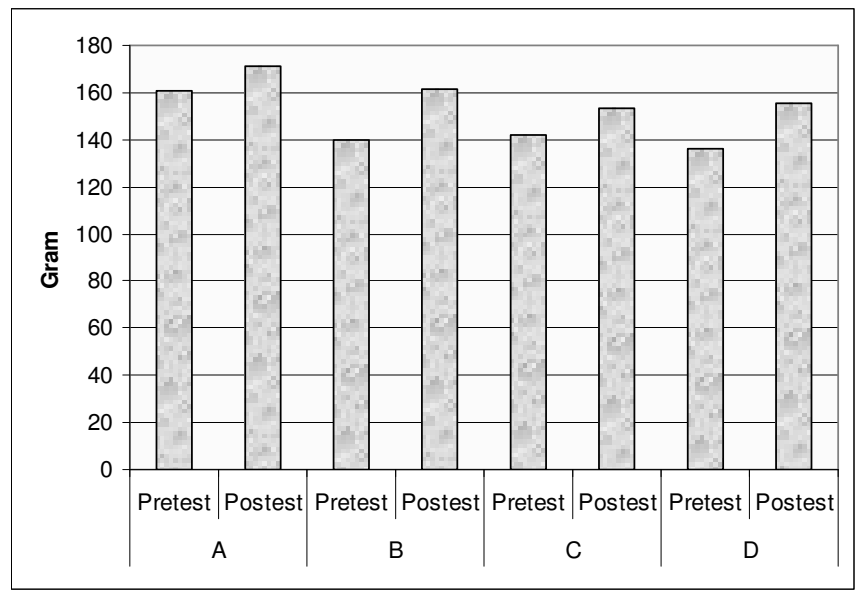

Gambar 4. Diagram Berat Badan

Keterangan:Uji statistic Tukey-test berpasangan merespon terdapat perbedaan perubahan berat badan sebelum dan sesudah test pada kelompok $A$ dengan $P$ $(0.001)<0.05$, kelompok $B$ dengan $P(0.000)<0.05$, kelompok $C$ dengan $P(0.005)<0.05$ dan perbedaan perubahan berat badan sebelum dan sesudah test kelompok D dengan $P(0.012)<0.05$.

Selama penelitian didapatkan data berat badan. Data berat badan yang dijadikan sebagai pedoman dalam perubahan berat badan adalah berat badan yang diambil pada saat pre test dan post test. Pada saat pre test didapatkan 
rata-rata berat badan kelompok $A$ sebesar 166.22 gram, kelompok B sebesar 148.52 gram, kelompok $C$ sebesar 144.22 gram dan kelompok D sebesar 144.58 gram.

Dari hasil uji statistik berat badan pre test dengan menggunakan One-way Anova menunjukkan bahwa terdapat perbedaan perubahan berat badan antara diet normal (kelompok A), diet aterogenik dengan minyak babi (kelompok B), diet aterogenik dengan minyak babi (kelompok C) dan diet aterogenik dengan minyak babi (kelompok $D$ ) dengan $P(0.029)<0.05$. Dari hasil uji lanjut Tukey (Beda Nyata terkecil) didapatkan bahwa $A$ berbeda dengan $B, C$ dan D.

Berat badan pada saat post test didapatkan bahwa pada rata-rata berat badan pada kelompok A sebesar 178.35 gram, kelompok B sebesar 172.88 gram, kelompok C sebesar 160.67 gram dan pada kelompok D sebesar 159.02 gram.

Hasil analisa berat badan post test dengan menggunakan One-way Anova menunjukkan bahwa tidak terdapat perbedaan perubahan berat badan antara diet normal (kelompok A), diet aterogenik dengan minyak babi (kelompok B), diet aterogenik dengan minyak kelapa sawit (kelompok C) dan diet aterogenik dengan VCNO (kelompok D) dengan $\mathrm{P}(0.098)>0.05$.

Dari data pre dan post test diketahui bahwa perubahan rata-rata berat badan pada kelompok $A$ meningkat sebesar 12.13 gram, kelompok $B$ meningkat sebesar 24.37 gram, kelompok $C$ meningkat sebesar 16.45 gram dan kelompok D meningkat sebesar 14.43 gram. Dari hasil Tukey-test berpasangan pada tabel 5.4 diketahui bahwa terdapat perbedaan perubahan berat badan sebelum dan sesudah test pada kelompok $A$ dengan $P(0.001)<$ 0.05 , kelompok $B$ dengan $P(0.000)<0.05$, kelompok $C$ dengan $\mathrm{P}(0.005)<0.05$ dan perbedaan perubahan berat badan sebelum dan sesudah test kelompok $D$ dengan $P$ $(0.012)<0.05$.

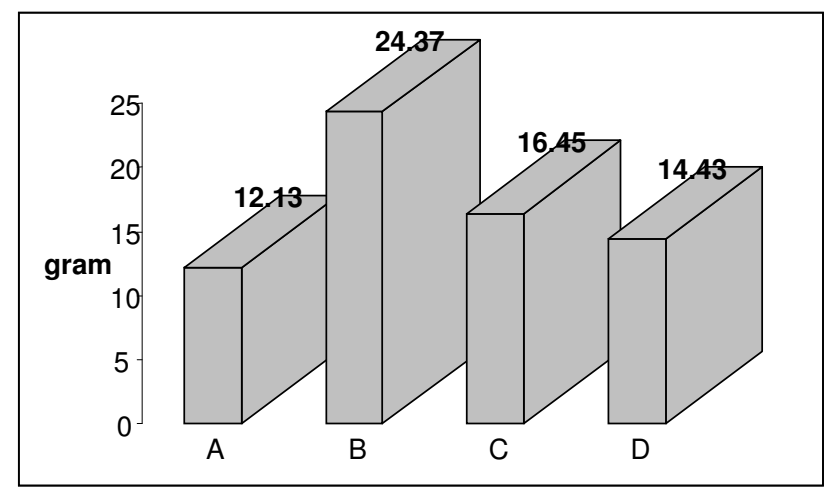

Gambar 5. Diagram Peningkatan Berat Badan

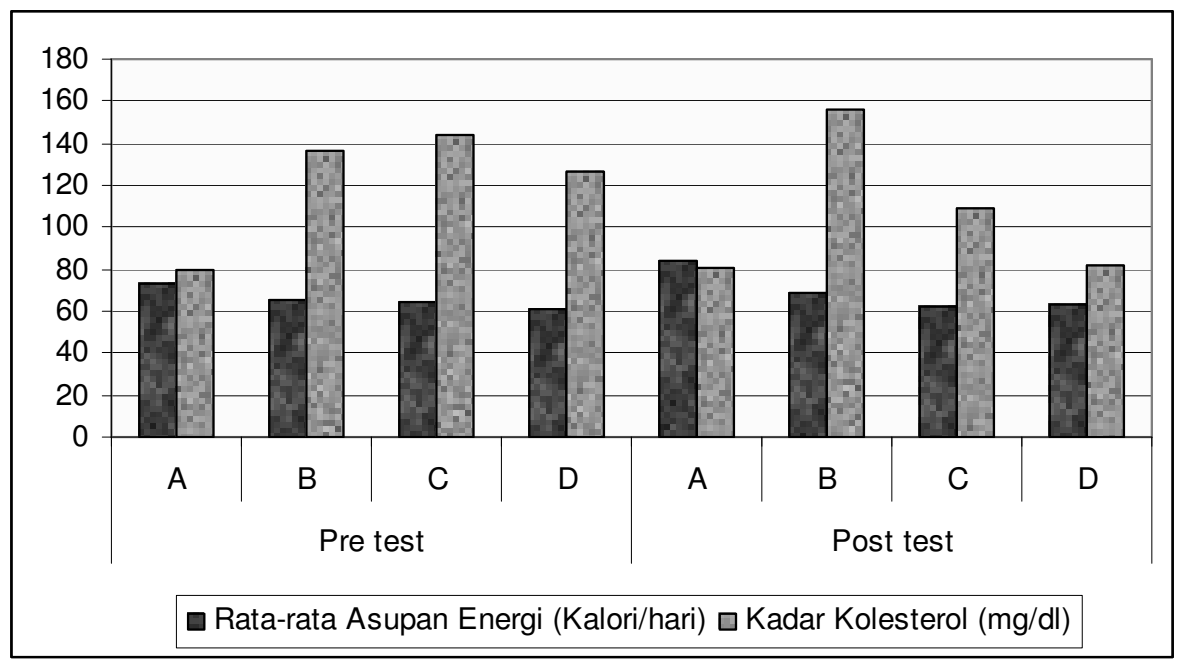

Gambar 6. Diagram Hubungan Asupan Energi dengan Kadar Kolesterol 


\section{Asupan Energi dan Kadar Kolesterol}

Dari data asupan energi dan kadar kolesterol menunjukkan bahwa besarnya rata-rata asupan energi tidak berpengaruh secara langsung terhadap rata-rata kadar kolesterol (Gambar 6). Pada kelompok A didapatkan bahwa asupan energi lebih tinggi dibandingkan dengan kelompok lain, akan tetapi kadar kolesterol kelompok A paling rendah dibandingkan dengan kelompok lain. Hal ini disebabkan oleh perbedaan kandungan zat gizi lain terutama lemak pada diet normal (kelompok A) dibandingkan dengan diet aterogenik (kelompok B, C dan D)

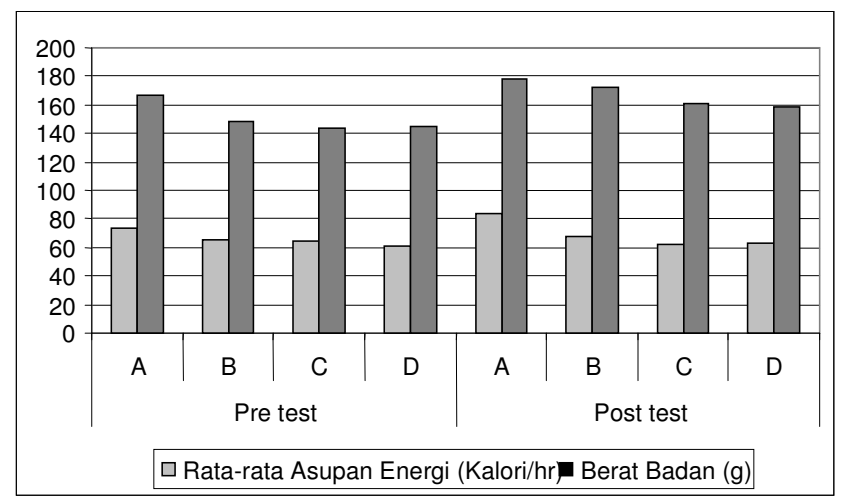

\section{Gambar 7.Diagram Hubungan Asupan Energi dengan Berat Badan}

\section{Asupan Energi dengan Berat Badan}

Dari data asupan energi dan berat badan didapatkan hasil bahwa jumlah rata-rata asupan energi meningkat dari pre test hingga post test kecuali pada kelompok C, akan tetapi penambahan berat badan terjadi pada semua kelompok. Pada kelompok $C$ terjadi penurunan rata-rata asupan energi tetapi tetap mengalami penambahan berat badan.

\section{DISKUSI}

\section{Asupan Energi dan Zat Gizi}

Rata-rata asupan pada saat post test pada tiap kelompok memiliki gambaran yang meningkat sebesar $5.3 \%$ dari rata-rata asupan energi pada saat pre test karena kebutuhan tikus semakin hari semakin meningkat sesuai pertambahan umur dan berat badannya. Akan tetapi, pada kelompok $C$ yaitu dengan penggantian minyak babi (pre test) menjadi minyak kelapa sawit (post test) memiliki gambaran rata-rata asupan energi yang menurun sebesar 2.62 Kalori dari asupan pada saat pre test. Pengkajian lebih lanjut mengenai hal tersebut menunjukkan bahwa aroma yang tidak harum dan tekstur pakan yang lebih mudah kering pada pemberian minyak kelapa sawit kurang disukai oleh tikus. Sehingga pemberian minyak kelapa sawit pada kelompok ini menurunkan nafsu makan tikus sehingga terjadi penu- runan rata-rata asupan energi. Sebaliknya pada kelompok $\mathrm{D}$, pemberian VCNO meningkatkan rata-rata asupan energi sebesar 0.84 Kalori atau $0.8 \%$ total pakan yang diberikan. Pemberian VCNO memberikan aroma harum yang menarik minat tikus dan membuat tekstur pakan menjadi lunak dan tidak mudah kering. Walaupun jumlah peningkatan ratarata asupan energi pada kelompok $D$ kecil tetapi hal ini menandakan ada pengaruh positif terhadap perbaikan nafsu makan pada tikus kelompok $D$ akibat pemberian VCNO. perbaikan nafsu makan ini meningkatkan jumlah asupan sehingga kemampuan VCNO untuk mempertahankan rasa kenyang tidak bertentangan dengan hasil ini.

\section{Kadar Kolesterol}

Dari hasil dan analisa data didapatkan bahwa pada diet dengan minyak babi selama 4 minggu dapat menaikkan Kadar kolesterol total sebesar $19.17 \mathrm{mg} / \mathrm{dl}$, sedangkan pada diet dengan minyak kelapa sawit menurunkan kadar kolesterol total sebesar $35.5 \mathrm{mg} / \mathrm{dl}$ dan pada diet dengan VCNO menurunkan kadar kolesterol total paling besar yaitu sebesar $45 \mathrm{mg} / \mathrm{dl}$.

Dari hasil tersebut membuktikan bahwa kandungan MCFA pada VCNO lebih banyak membantu dalam menurunkan kadar kolesterol didalam tubuh. Molekul MCFA relatif lebih kecil sehingga mudah larut dalam air. Dalam larutan yang netral MCFA merupakan elektrolit yang lemah dan molekulnya terionisasi. Sifat-sifat itulah yang menentukan bentuk metabolismenya yang lebih menguntungkan. Dengan sifat tersebut maka MCFA dapat mengatasi problem yang ditimbulkan oleh metabolisme lemak seperti dalam pencernaan, penyerapan, transport dari organ satu ke organ lain, maupun dalam usaha untuk mengurangi kadar lemak dalam darah (2).

Secara alami, VCNO tidak mengalami hidrogenasi. Hal ini menyebabkan VCNO tidak mengandung asam lemak trans (trans fatty acid) yang berakibat buruk pada kesehatan. Asam lemak trans ini dapat meningkatkan kadar kolesterol dalam darah. Anggapan konsumsi minyak dengan bahan dari kelapa dalam menu sehari-hari sesuai dengan kebutuhan tidak terbukti memberikan efek buruk terhadap kesehatan dan justru membina kesehatan jantung dan pembuluh darah (9). Hal tersebut juga ditunjang dengan hasil penelitian yang dilakukan terhadap masyarakat Srilanka menunjukkan rasio LDL/HDL meningkat setelah mengganti konsumsi minyak kelapa dengan minyak jagung. Bukti paling signifikan adalah penelitian Prior pada penduduk Poinesia yang beralih mengkonsumsi minyak modern justru mengalami peningkatan kadar kolesterol total (8).

Kandungan kolesterol dalam VCNO adalah dalam kisaran 0 hingga 14 ppm. Dimana nilai tersebut merupakan nilai yang paling rendah dibandingkan dengan kadar kolesterol pada minyak nabati lainnya walaupun kadar bahaya kolesterolnya jauh lebih rendah daripada lemak 
hewan dan produk susu. Selain itu kandungan MCFA pada VCNO paling tinggi dibandingkan dengan minyak nabati lainnya yaitu sebesar $63.5 \%$. Sedangkan pada minyak kelapa sawit mengandung kolesterol dalam kisaran 18 ppm atau lebih tinggi dibandingkan dengan VCNO dan mengandung MCFA sebesar $0.3 \%$ dari total kandungan lemaknya. Dilihat dari komposisi LCFA, minyak kelapa sawit mengandung lebih tinggi LCFA yaitu sebesar 51.2\% dibandingkan pada VCNO yang mengandung LCFA sebesar $28.10 \%$. Perbedaan komposisi tersebut sangat mempengaruhi kemampuan dalam menurunkan kadar kolesterol total. Dalam metabolismenya MCFA sangat berbeda dengan LCFA. LCFA akan membentuk trigliserida terlebih dahulu sebelum masuk kedalam sistem sirkulasi sehingga berakibat pada deposisi jaringan adiposa dan dapat membentuk kolesterol ester, sedangkan pada MCFA tidak. MCFA memiliki kemampuan langsung masuk portal venous blood untuk transpor langsung ke liver tanpa diresintesis terlebih dahulu menjadi tumpukan lemak (10).

\section{Berat Badan}

Dari hasil dan analisa data diketahui bahwa kenaikan berat badan yang tertinggi pada diet dengan minyak babi yaitu sebesar 24.37 gram dalam waktu 4 minggu, sedangkan pada diet dengan minyak kelapa sawit menaikkan berat badan sebesar 16.45 gram. Pada diet dengan VCNO menaikkan berat badan lebih sedikit dibandingkan dengan diet lainnya yaitu sebesar 14.43 gram.

Pengaruh penggunaan VCNO dihubungkan dengan penurunan berat badan berkaitan dengan kemampuan MCFA. Mekanisme kemampuan MCFA adalah sebagai berikut: (1) Medium Chain Fatty Acid mampu digunakan secara langsung sebagai sumber energi, dan tidak ditimbun pada jaringan adiposa. (2) Kandungan MCFA mendorong pembakaran LCFA penyebab obesitas, hal ini karena fungsi MCFA memperbaiki asam lemak tubuh secara sinergis dengan asam lemak esensial sehingga efisiensi penggunaan asam lemak esensial juga meningkat $100 \%$. (3) Kemampuan ini didukung kemampuan MCFA dalam mengaktifkan insulin sehingga penggunaan energi pada metabolisme ditingkatkan (9). Selain itu, Syah, 2005 mengungkapkan bahwa minyak kelapa (minyak kelapa sawit dan VCNO) dapat membantu mengurangi berat badan. Melalui mekanisme insulin, MCT akan dibawa ke dalam lever untuk segera mengalami pembakaran. Proses pembakaran akan menyebabkan suhu tubuh meningkat, dengan kondisi ini maka tubuh memerlukan energi lebih banyak (8).

Penelitian lain oleh St-Onge and Jones menyebutkan ada beberapa peran MCFA terhadap penurunan berat badan yaitu : (1) efek MCFA terhadap Enegy Expenditure $(E E)$, pemberian MCFA ternyata menyebabkan peningkatan EE sehingga terjadi penurunan berat badan tanpa menurunkan intake energi, (2) efek MCFA terhadap Fat Deposition, MCFA meningkatkan EE hingga berakibat terhadap menurunnya cadangan lemak tubuh terutama pada jenis kelamin laki-laki/jantan, (3) efek MCFA terhadap Food intake and satiety, konsumsi MCFA memberikan kedaan untuk merasa lebih lama kenyang dibandingkan dengan MCFA sehingga konsumsi makanan menjadi terkendali (11).

Pada diet dengan pemberian minyak kelapa sawit dan VCNO menghasilkan peningkatan berat badan yang tidak sama. Dalam hal ini dipengaruhi oleh kandungan MCT yang berbeda pada minyak kelapa sawit dibandingkan dengan VCNO. Kandungan MCT pada minyak kelapa sawit $0.3 \%$ dari total lemak, sedangkan kandungan MCT pada VCNO adalah $63.5 \%$ dari total lemak (8).

\section{KESIMPULAN}

Dari penelitian dan analisis data didapatkan kesimpulan bahwa ada perbedaan pengaruh pemberian minyak kelapa sawit dan VCNO terhadap penurunan kadar kolesterol total pada tikus yang diberi diet aterogenik

\section{SARAN}

1. Perlunya upaya sosialisasi maupun optimalisasi penggunaan VCNO dimana Indonesia merupakan produsen kelapa sehingga dapat membantu masyarakat dalam mengatasi masalah kesehatan

2. Perlu dilakukan penelitian lebih lanjut mengenai dosis penggunaan minyak kelapa sawit dan VCNO yang tepat dan aman dalam mempercepat penurunan kadar kolesterol maupun berat badan

3. Perlu dilakukan penelitian lebih lanjut mengenai cara pemasakan dalam hal waktu dan suhu pemasakan serta cara penyimpanan yang aman dan tepat guna keamanan konsumsi sebagai aplikasi penggunaan dalam masyarakat.

\section{DAFTAR KEPUSTAKAAN}

1. Tha. Minyak Kelapa Hasilkan Energi, Jawa Pos, Senin 10 Januari 2005; 39.

2. Sibuea, Posman. "VCNO", Penyembuh Ajaib dari Buah Kelapa. 2004. http://www.kompas.co.id/kompas-cetak/0412/22/ Diakses: 10 Januari 2005

3. Winarno FG. Minyak Goreng Dalam Menu Masyarakat. Balai Pustaka : Jakarta; 1999; 21-51.

4. Yun. Kelapa untuk Berdayakan Masyarakat Pesisir. 2004. http://www.kompas.com/kompas-cetak/0412/02/bahari 11412428.htm Diakses : 11 Januari 2005 
5. Lee, Lita. Coconut Oil: Why it is Good For You. 2001.http://www.coconut.oil-info.cpm/coconut/oil.htm. Diakses : 10 Januari 2005,

6. Notoatmojo, Soekidjo. Metodologi Penelitian Kesehatan. Rineka Cipta : Jakarta; 2002.

7. Kemas, Hanafiah Ali. Rancangan Percobaan Teori dan Aplikasi. Jakarta: Raja Grafindo Persada; 1995.

8. Syah, Andi Nur Alam. Virgin Coconut Oil Minyak Penakluk Aneka Penyakit. Jakarta: AgroMedia Pustaka; 2005; 18-20, 43-46, 49-56.

9. Sutarmi dan Rozaline, Hartin. Taklukkan Penyakit dengan VCO. Jakarta: Penebar Swadaya; 2005; 10-23.

10. Mahan L, Kathleen and stump, Sylvia Escott. Krauses's Food, Nutrition and Diet Therapy. USA: W.B. Saunders Company. 1996; 602

11. St-Onge, Marie-Pierre and Jones, Peter JH..Physiological Effects of Medium-Chain Triglycerides: Potential Agents in the Preventionof Obesity1. School of Dietetics and Human Nutrition, McGill University Ste-Anne-de-Bellevue, Quebec, Canada, H9X 3V9. 2002: 329-333., www.nutrition.org. Diakses : 18 Juli 2005 